\title{
ANALISIS EFISIENSI SISTEM PENDINGIN PADA KERETA API KELAS EKONOMI
}

${ }^{1}$ Erika Fitriani Saripudin, ${ }^{2}$ Moch. Djaohar, ${ }^{3}$ Aris Sunawar

1,2,3 Pendidikan Teknik Elektro, Fakultas Teknik, Universitas Negeri Jakarta

1,2,3 Email: erikha13@gmail.com,djaohar@unj.ac.id, arissunawar@unj.ac.id

\begin{abstract}
The purpose of this study was to determine the efficiency of the cooling system (Split AC) on economy class trains. The method used in this study is a qualitative analysis research method. Where the results of this study are in the form of efficient or not the performance of AC Split on the economy train (K3). Based on the data obtained from the research results obtained that the largest compressor power input is $7332.79 \mathrm{~W}$ and the smallest compressor power of 6906.22 W produces the largest AC cooling load output at $11200.56 \mathrm{~W}$ and the smallest cooling load at $9641.55 \mathrm{~W}$. From The resulting COP value can be concluded that the use of Split AC in the economy train is less efficient because the COP value is still below the SNIO3-6390-2000 standard which is a minimum of 2.6.
\end{abstract}

Keywords: Split AC, train, cooling load, efficiency.

\begin{abstract}
Abstrak
Tujuan dari penelitian ini adalah untuk mengetahui efisiensi sistem pendingin (AC Split) pada kereta api kelas ekonomi. Metode yang digunakan dalam penelitian ini adalah metode penelitian analisis kualitatif. Dimana hasil dari penelitian ini adalah berupa efisien atau tidaknya performansi AC Split pada kereta api ekonomi (K3). Berdasarkan data hasil penelitian yang diperoleh didapat bahwa input daya kompresor terbesar sebesar 7332,79 W dan daya kompresor terkecil sebesar 6906,22 W menghasilkan output beban pendinginan AC terbesar pada sebesar 11200,56 W dan beban pendinginan terkecil pada sebesar 9641,55 W. Dari nilai COP yang dihasilkan dapat disimpulkan bahwa penggunaan AC Split pada kereta api ekonomi kurang efisien karena nilai COPnya masih dibawah standar SNI03-6390-2000 yaitu minimal 2,6.

Kata kunci: AC Split, kereta api, beban pendingin, efisiensi.
\end{abstract}

\section{PENDAHULUAN}

Seiring dengan meningkatnya populasi di Indonesia, kebutuhan akan transportasi massal yang mampu mengimbangi peningkatan populasi terus meningkat tiap tahunnya. Perkembangan tersebut secara tidak langsung menyebabkan perusahaan penyedia jasa transportasi berlomba-lomba dalam menghasilkan transportasi yang mampu mengimbangi peningkatan populasi serta tidak meninggalkan aspek keselamatan dan kenyamanan. Salah satunya adalah PT. Kereta Api Indonesia (PERSERO) yang menyediakan jasa transportasi massal yang kini banyak diminati masyarakat Indonesia. Saat ini PT. KAI telah melakukan suatu terobosan, yaitu memasang pendingin udara atau AC pada kereta api kelas ekonomi (K3) dengan melakukan modifikasi, sehingga dapat dipasang AC Split (AC rumah). Tujuan pemasangan $\mathrm{AC}$ pada kereta api kelas ekonomi (K3) adalah untuk meningkatkan kenyamanan kepada pengguna jasa kereta api, sehingga pengguna jasa kereta api sekarang ini tidak lagi merasakan suhu panas pada siang dan malam hari. Namun dengan alasan pertimbangan biaya, maka PT. Kereta Api Indonesia (PERSERO) sepakat untuk memasang AC Split pada kereta api kelas ekonomi (K3), bukan AC Central yang lazim digunakan pada alat transportasi lainnya.

Seperti dikutip di laman finance.detik.com pada 11 Maret 2014, Pemasangan AC split atau AC rumah ini hanya berlangsung sementara. Penggunaan AC split ini hanya dilakukan sambil menunggu kedatangan kereta baru yang dipesan oleh KAI. Karena hingga tahun 2020, KAI akan mendatangkan 1.500 unit kereta kelas ekonomi, bisnis dan eksekutif. Namun faktanya peneliti masih menemui rangkaian kereta api baru yang menggunakan AC split. Berdasarkan uraian di atas, peneliti tertarik untuk meneliti apakah penggunaan AC Split pada kereta api kelas ekonomi (K3) lebih efisien dalam penggunaan daya dan kapasitas pendinginan yang dihasilkan sehingga masih digunakan hingga saat ini.

Adapun masalah yang dibatasi dalam penelitian ini adalah:

1. Penelitian dilakukan di PT. Kereta Api Indonesia (PERSERO).

2. Penelitian dilakukan pada 7 gerbong kereta api kelas ekonomi (K3).

3. Penelitian dilakukan dengan beban penumpang kosong.

4. Penelitian ini hanya meneliti mengenai efisiensi AC Split pada kereta api kelas ekonomi dengan menganalisis hasil 
perbandingan beban pendinginan dan input daya kompresor.

Tujuan dari penulisan skripsi ini adalah untuk mengetahui efisiensi AC Split pada kereta api kelas ekonomi (K3). Berdasarkan rumusan masalah yang disampaikan diatas maka penulis akan membuat sebuah penelitian dengan judul "Analisis Efisiensi Sistem Pendingin pada Kereta Api Kelas Ekonomi"

\section{METODOLOGI PENELITIAN}

Metode yang digunakan dalam penelitian ini adalah metode penelitian analisis kualitatif. Dimana hasil dari penelitian ini adalah berupa efisien atau tidaknya performansi AC Split pada kereta api ekonomi (K3). Analisis data adalah proses mencari dan menyusun secara sistematis data yang diperoleh dari hasil wawancara, catatan lapangan, dan dokumentasi, dengan cara mengorganisasikan data ke dalam kategori, menjabarkan ke dalam unit-unit, melakukan sintesa, menyusun ke dalam pola, memilih mana yang penting dan yang akan dipelajari, dan membuat kesimpulan sehingga mudah difahami oleh diri sendiri maupun orang lain (Lexy, $\mathrm{J}: 2007)$. Analisis data diperlukan untuk menganalisis efisiensi AC Split pada kereta api kelas ekonomi (K3).

\section{HASIL DAN PEMBAHASAN}

Beban pendinginan dihasilkan dari persamaan $\mathrm{Q}=\mathrm{U} \times \mathrm{A} \times \Delta \mathrm{T}$. Dimana $\mathrm{Q}=$ Beban Pendinginan (Watt), $U=$ Koefisien Perpindahan Panas $\left(\mathrm{W} / \mathrm{m}^{2} .{ }^{\circ} \mathrm{C}\right), \mathrm{A}=$ Luas Penampang $\left(\mathrm{m}^{2}\right)$ dan $\Delta \mathrm{T}=$ Selisih temperatur input dan output evaporator $\left({ }^{\circ} \mathrm{C}\right)$. Hasil pengukuran beban pendinginan dirangkum dalam Tabel 1 berikut.

Tabel 1. Beban Pendinginan Tiap Gerbong

\begin{tabular}{ll}
\hline & W (Watt) \\
\hline Gerbong 1 & 7332,79 \\
Gerbong 2 & 7319,50 \\
Gerbong 3 & 7314,08 \\
Gerbong 4 & 7276,93 \\
Gerbong 5 & 7275,86 \\
Gerbong 6 & 7256,97 \\
Gerbong 7 & 6906,22 \\
\hline
\end{tabular}

Dari Tabel 1 dapat diketahui bahwa beban pendinginan terbesar terdapat pada gerbong 2 sebesar 11200,56 W dan beban pendinginan terkecil terdapat pada gerbong 6 sebesar 9641,55 W. Faktor yang mempengaruhi tingginya beban pendinginan adalah tingginya temperatur dalam gerbong.

Setelah mendapatkan beban pendinginan sebagai output AC Split, kemudian mengukur daya kompresor $(\mathrm{kW})$ sebagai input AC Split yang diperoleh dari hasil kali antara tegangan $(\mathrm{V})$, arus (A), dan $\cos \phi$ yang telah diukur menggunakan alat Clamp Meter. Hasil pengukuran dapat dilihat dalam Tabel 2 berikut:

Tabel 2. Daya Kompresor

\begin{tabular}{cc}
\hline & Q (Watt) \\
\hline Gerbong 1 & 10913,09 \\
Gerbong 2 & 11200,56 \\
Gerbong 3 & 10282,85 \\
Gerbong 4 & 10249,68 \\
Gerbong 5 & 10238,62 \\
Gerbong 6 & 9641,55 \\
Gerbong 7 & 10260,73 \\
\hline
\end{tabular}

Dari Tabel 2 di atas dapat dilihat bahwa daya kompresor mengalami penurunan seiring dengan letak gerbong yang semakin menjauhi generator. Pada gerbong 1 terlihat daya kompresor sebesar $7332,79 \mathrm{~W}$ menjadi daya kompresor yang terbesar sedangkan gerbong 7 dengan daya kompresor sebesar 6906,22 W menjadi daya kompresor terendah. Hal ini juga dipengaruhi oleh tegangan dan arus yang berubah seiring dengan semakin jauh jarak gerbong dari generator.

Untuk menentukan tingkat performa atau efisiensi, setiap AC Split harus dicari koefisien performansinya yaitu COP (Coefficient of Performance). Menurut SNI, AC Split harus memiliki COP minimal 2,6. COP dicari berdasarkan persamaan 2.2 yaitu:

$$
\text { COP aktual }=\frac{\text { Beban Pendinginan }(k W)}{\text { Daya Kompresor }(k W)}
$$

Hasil perhitungan COP AC Split pada tiap gerbong dapat dilihat dalam Tabel berikut: 
Tabel 3. COP Gerbong 1

\begin{tabular}{cc}
\hline AC Split No... & COP \\
\hline 1 & 1,39 \\
2 & 2,03 \\
3 & 1,18 \\
4 & 1,02 \\
5 & 2,86 \\
6 & 1,19 \\
\hline
\end{tabular}

Tabel 4. COP Gerbong 2

\begin{tabular}{cc}
\hline AC Split No... & COP \\
\hline 1 & 1,43 \\
2 & 2,21 \\
3 & 1,35 \\
4 & 1,03 \\
5 & 2,78 \\
6 & 1,12 \\
\hline
\end{tabular}

Tabel 5. COP Gerbong 3

\begin{tabular}{cc}
\hline AC Split No... & COP \\
\hline 1 & 1,20 \\
2 & 2,00 \\
3 & 1,24 \\
4 & 1,02 \\
5 & 2,43 \\
6 & 1,15 \\
\hline
\end{tabular}

Tabel 6. COP Gerbong 4

\begin{tabular}{cc}
\hline AC Split No... & COP \\
\hline 1 & 1,09 \\
2 & 2,08 \\
3 & 1,01 \\
4 & 1,11 \\
5 & 2,54 \\
6 & 1,29 \\
\hline
\end{tabular}

Tabel 7. COP Gerbong 5

\begin{tabular}{cc}
\hline AC Split No... & COP \\
\hline 1 & 1,21 \\
2 & 1,84 \\
3 & 1,06 \\
4 & 1,01 \\
5 & 2,61 \\
6 & 1,35 \\
\hline
\end{tabular}

Tabel 8. COP Gerbong 6

\begin{tabular}{cc}
\hline AC Split No... & COP \\
\hline 1 & 1,19 \\
2 & 1,91 \\
3 & 0,99 \\
4 & 1,01 \\
5 & 2,27 \\
6 & 1,17 \\
\hline
\end{tabular}

Tabel 9. COP Gerbong 7

\begin{tabular}{cc}
\hline AC Split No... & COP \\
\hline 1 & 1,36 \\
2 & 2,19 \\
3 & 1,22 \\
4 & 1,32 \\
5 & 2,08 \\
6 & 1,20 \\
\hline
\end{tabular}

Berdasarkan tabel-tabel di atas dapat dilihat bahwa rata-rata nilai COP tiap unit AC pada 7 gerbong masih dibawah standar SNI yaitu sebesar 2,6.

\section{KESIMPULAN DAN SARAN Kesimpulan}

Berdasarkan pembahasan yang telah diuraikan sebelumnya, maka diperoleh kesimpulan.

1. Beban pendinginan terkecil berada pada gerbong 6 dengan total beban 9641,55 W. Sedangkan beban pendinginan terbesar berada pada gerbong 2 dengan total beban $11200,56 \mathrm{~W}$. Hal yang mempengaruhi beban pendinginan adalah besar kecilnya perbedaan temperatur input dan output pada evaporator, semakin besar selisihnya maka beban pendinginan akan semakin besar.

2. Input daya kompresor terbesar terdapat pada gerbong 1 sebesar $7332,79 \mathrm{~W}$ dan daya kompresor terkecil terdapat pada gerbong 7 sebesar 6906,22 W. Hal yang mempengaruhi besar daya kompresor adalah besar tegangan, arus dan $\cos \varphi$. Semakin jauh jarak gerbong dengan generator, maka daya kompresornya akan semakin kecil.

3. Dari nilai COP yang dihasilkan, dapat disimpulkan bahwa penggunaan AC Split pada kereta api kelas ekonomi masih kurang efisien karena perbandingan input daya 
kompresor dan output beban pendinginannya tidak sesuai standar SNI yaitu 2,6.

\section{Saran}

Pihak Kereta Api Indonesia (PERSERO) harus melakukan peninjauan kembali mengenai penggunaan AC Split pada kereta api. Alangkah baiknya jika dilakukan penambahan kapasitas pendinginan pada $\mathrm{AC}$ dan perencanaan tata letak dari tiap unit AC agar dihasilkan beban pendinginan yang maksimal.Penelitian ini memiliki keterbatasan keterkaitan dengan segmen, karena keterbatasan waktu peneliti. Penelitian selanjutnya disarankan untuk melakukan penelitian pada segmen yang lebih panjang, tahun pemasangan kabel, dan jumlah beban yang tinggi. Hal tersebut menarik untuk diteliti karena setiap Panjang segmen, tahun pemasangan kabel, dan jumlah beban yang tinggi dapat mempengaruhi kualitas kabel tegangan menengah pada jaringan distribusi tenaga listrik.

\section{DAFTAR PUSTAKA}

[1] Homzah, Ozkar F. 2016. Studi Kinerja Mesin Pengkondisi Udara Tipe Terpisah (Ac Split) Pada Gerbong Penumpang Kereta Api Ekonomi. Jurnal Teknik Mesin Universitas Tridinanti Palembang.

[2] Darminto, Dwi Prastowo dan Rifka Julianty. 2002. Analisis Laporan Keuangan: Konsep dan Manfaat. Yogyakarta: AMP-YKPN

[3] Gunawan, Ricky. 1988. Pengantar Teori Teknik Pendingin (Refrijerasi). Jakarta: Departemen Pendidikan dan Kebudayaan.

[4] Hara, Supratman, W.F.Stoecker dan J.W.Jones. 1982. Refrigerasi dan Pengkondisian Udara edisi kedua. Jakarta: Erlangga.

[5] Hidayat, Taufik dan Firdausa Retnaning Restu. 2017. Pengembangan Desain Sistem Pengkondisian Udara Kereta Api Oleh PT. INKA (Persero). Jurnal Penelitian Transportasi Darat Volume 19, Nomor 1.
[6] Moleong, Lexy J. 2007. Metode Penelitian Kualitatif. Bandung: Remaja Rosdakarya

[7] Nizar, Muhammad Afdi. Syahrul, dan Ardiyos. 2000. Kamus Lengkap Ekonomi: Istilah-istilah Akutansi, Keuangan dan Investasi. Jakarta: Citra Harta Prima

[8] Munandar, Aris. Wiranto dan Saito Heizo. 1986. Penyegaran Udara. Jakarta: Pradya Paramitha.

[9] Miller, Rex. 1983. Refrigeration and Air Conditioning Technology. New York: Bennett Publishing Company

[10] Puspitasari, Mariana Diah. 2017. Analisa Perbandingan Efisiensi Daya Dan Kapasitas Pendinginan Antara AC Central Dan AC Split Pada Kereta Ekonomi. Jurnal Perkeretaapian Indonesia Volume II Nomor 2.

[11] Sumanto. 2004. Dasar-dasar Mesin Pendingin. Yogyakarta: ANDI

[12] Wang, Shan K. 2000. Handbook of Air Conditioning and Refrigeration. New York: McGraw - Hill.

[13] Sugiyono. 2016. Metode Penelitian Kuantitatif, Kualitatif, dan R\&D. Bandung: CV Alfabeta
[14] Peraturan Menteri Perhubungan Nomor: KM. 41 Tahun 2010

[15] Standar Nasional Indonesia 03-63902000 